батарей космического назначения. Вопросы проектирования и производства конструкиий летательных аппаратов. 1999. Вып. 4(17). C. $68-77$.

5. Гайдачук А. В., Карпикова О. А., Кондратьев А. В., Сливинский М. В. Сотовые заполнители и панельные конструкиии космического назначения: монограф. в 2 т. Харьков: Нац. аэрокосм. ун-т им. Н.Е. Жуковского «Харьк. авиац. ин-т», 2012. Т. 1. 279 с.

6. Яновский Ю. Г., Сирота А. Г., Богданов В. В., Филиппенков П. А. Особенности физико-механических свойств композиционных материалов на основе полимеров и углеродных волокон. Обзор. Механика композиционных материалов и конструкичии. 1997. № 2. C. 101-117.

DOI https://doi.org/10.30525/978-9934-588-79-2-1.28

\title{
ДОСЛІДЖЕННЯ ВПЛИВУ ІОННО-ПЛАЗМОВИХ ПОКРИТТІВ НА ЗНОС ТРИБОСПОЛУЧЕНЬ ОБ'ЄМНОГО ГІДРОПРИВОДУ
}

\section{Щукін О. В.}

кандидат технічних наук, дочент, кафедра будівельних і дорожніх машин

Харківського національного автомобільно-дорожнього університету

Орел О. В.

кандидат технічних наук, дочент, кафедра будівельних і дорожніх машин

Харківського національного автомобільно-дорожнього університету

Резніков О. О.

кандидат технічних наук, доцент, кафедра будівельних і дорожніх машин

Харківського начіонального автомобільно-дорожнього університету м. Харків, Украӥна

На сьогоднішній день основними методами нанесення плазмових зносостійких покриттів, які істотно підвищують експлуатаційні характеристики матеріалів робочих поверхонь, є хімічне осадження з газового середовища і конденсація твердої речовини в умовах іонного бомбардування (КІБ) $[1$, с. $43 ; 2$, с. 98]. Він використовується, як ос- 
новний засіб у боротьбі проти корозії і різних впливів робочого середовища, в якому експлуатуються деталі.

Разом з тим використання методу КІБ являє собою великий інтерес в силу того, що він дозволяє варіювати складом покриття і як результат, отримувати корозійностійкі, зносостійкі з високими характеристиками міцності шари, які мають надійну адгезію з основним металом $[1$, c. $13 ; 2$, с. $61 ; 3$, с. 196$]$.

Актуальною проблемою $є$ вибір оптимального складу і режиму нанесення іонно-плазмового покриття (ІПП), яке б дозволило вирішити проблему зниження зносу трибосполучень (поршні-стінки циліндрів аксіально-поршневого насоса) об'ємного гідроприводу будівельних і дорожніх машин при мінімальних витратах на технологію нанесення останнього.

Для вибору складу ІПП були проведені лабораторні випробування на машині тертя СМЦ-2.

Випробування на машині тертя СМЦ-2 проводилися за схемою «колодка-ролик» (рис. 1), яка імітує умови роботи нижчих кінематичних пар.

Характеристика зразків була наступна: матеріал - сталь ШХ15; твердість використовуваної сталі - 62HRC; шорсткість поверхонь 0,032 мкм.

Такі показники сталі повністю відповідають матеріалу, з якого виготовляються реальні поршні аксіально-поршневих насосів.

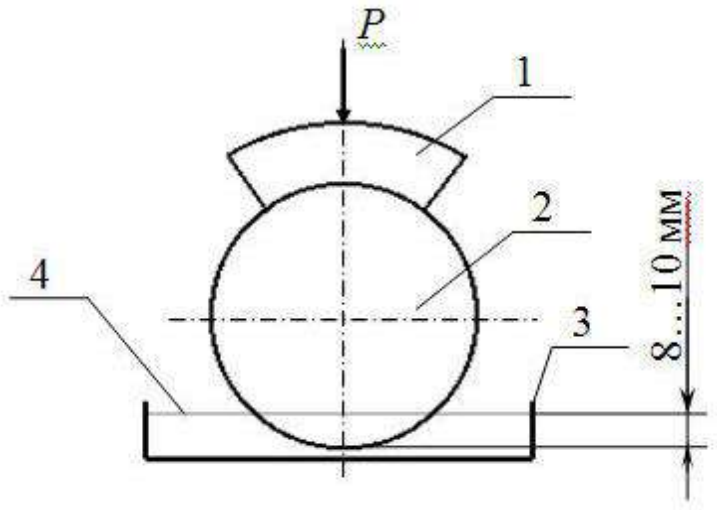

Рис. 1. Схема випробувань колодки і ролика на машині тертя СМЦ-2

1 - колодка; 2 - ролик; 3 - кювета; 4 - рівень робочої рідини 
Діаметр роликів становив 50 мм, ширина - 12 мм, ширина колодки - 10 мм, частота обертання ролика - 500 об/хв. Ролики занурювалися в кювету з мастилом I-Г-А-32.

Режим випробувань зразків був наступний. Чотири партії роликів i колодок піддавалися припрацюванню протягом 15 хвилин при навантаженні, що відповідає вазі каретки машини. Потім випробування тривали протягом 4 години 45 хвилин для кожної з чотирьох партій колодок при навантаженні $50 \mathrm{H}$ (перша партія), 100 Н (друга партія), 150 Н (третя партія) і 200 Н (четверта партія).

Знос зразків визначали по втраті ними маси за час випробування за допомогою зважування на аналітичних вагах Sartorius CC 111 з точністю до $\pm 0,000001$ г $з$ доведенням зразків до постійної маси.

Кожна з чотирьох партій роликів була розділена на чотири групи:

- перша група - 8 роликів з термообробкою;

- друга група - 8 роликів з IПП TiN;

- третя група -8 роликів з ІПП MoN;

- четверта група -8 роликів з IПП $\mathrm{TiN}-\mathrm{Cr}_{2} \mathrm{~N}$.

Вибір саме таких матеріалів покриття пояснюється тим, що дані ІПП найбільш часто використовуються для деталей об'ємного гідроприводу [1, с. $45 ; 2$, с. 145$]$.

Для отримання достовірних результатів експерименти проводилися по вісім разів з використанням нових зразків кожної групи. Така повторюваність експериментів обумовлена досвідом проведення зносних випробувань [4, с. 132] і розраховувалася ітераційним методом. Результати випробувань наведено на рис. 2.

3 графіків, представлених на рис. 2, видно, що сумарний знос зразків після випробувань на машині тертя СМЦ-2 збільшується прямопропорційно підвищенню навантаження на них. При цьому найбільший знос при всіх навантаженнях має місце при випробуваннях зразків, схильних до термообробки, а найменший - у зразків, на які було нанесено IПП $\mathrm{TiN}_{-} \mathrm{Cr}_{2} \mathrm{~N}$ (в 2,78 рази при навантаженні $50 \mathrm{H}$ і в 2,08 рази при навантаженні $200 \mathrm{H})$. Звертає на себе увагу той факт, що в міру підвищення навантаження різниця в зносі всіх чотирьох партій зразків збільшується.

Знос зразків з ІПП MoN i TiN при всіх навантаженнях менше в порівнянні із зразками після термообробки, але більше, ніж при використанні ІПП $\mathrm{TiN}-\mathrm{Cr}_{2} \mathrm{~N}$.

Таким чином, можна зробити висновок про те, що для зниження зносу зразків, виготовлених з термообробленої сталі ШХ15, необхідно використовувати IПП $\mathrm{TiN}-\mathrm{Cr}_{2} \mathrm{~N}$. 


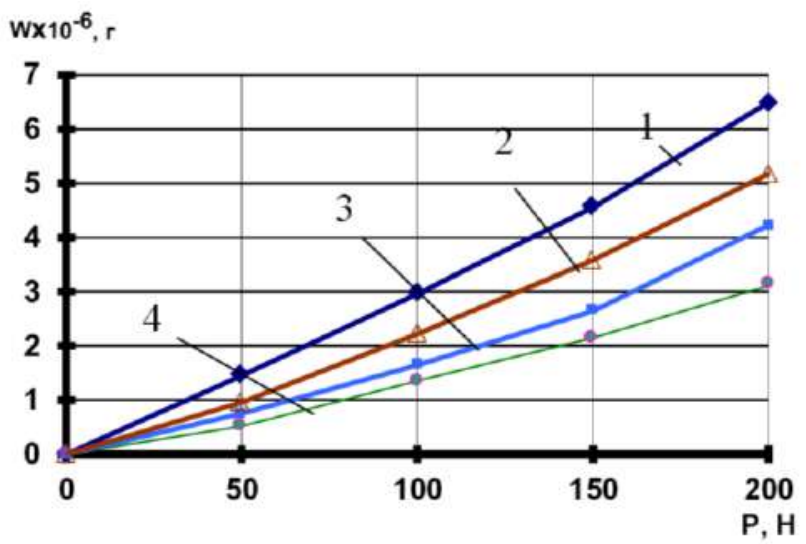

Рис. 2. Залежність зносу $W$ досліджуваних матеріалів від прикладеної навантаження $P$ 1 - термооброблена сталь ШХ15;

\section{2 - сталь ШХ15 з покриттям МоN; 3 - сталь ШХ15 з покриттям} TiN; 4 - сталь ШX15 3 покриттям TiN-Cr 2 N

\section{Література:}

1. Роик Т.А., Глушкова Д.Б., Рыжков Ю.В. Повышение износои коррозионной стойкости деталей объемного гидропривода нанесением ионно-плазменных покрытий. Харьков, 2012. 112 с.

2. Венцель С.С., Орел О.В., Щукін О.В. Підвищення якості мастил, палив і трибовузлів машин. Х.: ФОП Бровін О.В., 2017. 264 с.

3. Ventsel Ye., Orel O., Shchukin O., Saienko N., Kravets' A. Dependence of Wear Intensity on Parameters of Tribo Units. Tribology in Industry. 2018. Vol. 40, № 2. P. 195-202. DOI: 10.24874/ti.40.02.03. (Scopus)

4. Зажигаев Л.С., Кишьян А.А., Романиков Ю.И. Методы планирования и обработки результатов физического эксперимента. М.: Атомиздат, 1978. $232 \mathrm{c}$. 